ORIGINAL ARTICLE

\title{
Epidemiology of Typhoid in Nepal: Review of Literature to Identify High Burden Area for Potential Use of Typhoid Vaccine
}

\author{
Birendra Prasad Gupta ${ }^{1}$, Tarun Saluja ${ }^{2}$, Sushant Sahastrabuddhe ${ }^{3}$
}

\begin{abstract}
Aim and objective: Enteric fever has caused significant morbidity and will even get worse if the predisposing risk factors of the disease are not controlled. The rainy season accounts for the high incidence of enteric fever along with other diarrheal diseases in Nepal. This study aims to screen the high burden zone of typhoid cases in Nepal for the prospective use of typhoid conjugate vaccine for the disease.

Materials and methods: We searched Medline, Embase, Cochrane, and the World Health Organization (WHO) website for scientific literature published until December 2018. Additional publications identified through grey literature search, outbreak news-related online databases, and national reports from Nepal were reviewed. We summarized reported outbreaks of typhoid in Nepal by reported year, region, size of the outbreak, and major age group affected followed by the number of typhoid cases by year, region, and district reported to the Epidemiology and Disease Control Division (EDCD).

Results: Since the first report of the typhoid outbreak in 1984, there have been multiple publications describing typhoid in Nepal. Studies were conducted predominantly from Kathmandu valley during the rainy season; however, outbreaks have been reported at other parts of Nepal including Hilly and Mountain regions. While all age groups were affected by typhoid, children to young adults were frequently reported with the highest proportion. The data show that typhoid cases are on increase in all the five development regions (Eastern, Central, Western, MidWestern, and Far-Western Development region), except in the far western region where the slight decrease was observed from 2013/2014 to 2014/2015 while an increasing trend was observed after 2015/2016.

Conclusion: We found typhoid cases are on increase and have become a pressing public health issue and concerned authorities should put their serious efforts to mitigate the problem. There are many challenges on the way to control the disease, inaccurate diagnosis, inadequate treatment, and increasing multidrug resistance are a few of them. A combined approach of vaccination and water, sanitation, and hygiene (WASH) may lead to a considerable drop in the incidence of this disease.
\end{abstract}

Keywords: Nepal, Outbreak, Surveillance, Typhoid, Typhoid conjugate vaccine.

Pediatric Infectious Disease (2021): 10.5005/jp-journals-10081-1297

\section{INTRODUCTION}

Enteric fever is a common health problem in many countries, especially in developing countries. ${ }^{1}$ Each year, there are 11.9-26.9 million cases and 129,000-217,000 death counts globally. ${ }^{2,3}$ There are striking variations in annual global incidence ranging from $<0.1$ per 100,000 people in North America to 976 per 100,000 people in South Asia. ${ }^{4}$ The Indian subcontinent including Nepal has to face the heat of the disease with an estimated approximate 6 million cases each year. ${ }^{5}$ The S. typhi and S. paratyphi serotype A, B, or C are pathogen responsible for enteric fever worldwide. ${ }^{6}$ The potential source of acquiring infection is caused by the ingestion of contaminated food and water containing the S. typhi and/or S. paratyphi ${ }^{7}$ and the contributing factors are poor hygiene and sanitation. ${ }^{8}$

There has been considerable antibiotic resistance against typhoid reported from Nepal, chloramphenicol, amoxicillin, and cotrimoxazole at the initial stage and later to fluoroquinolones. ${ }^{9}$ Vaccination could be one of the significant tools in reducing the disease burden. To date, many generations of vaccines have been developed, starting from killed typhoid vaccines to, live attenuated and recently conjugate vaccines; of which Typbar TCV got prequalification by World Health Organization (WHO) in early 2018 and is a licensed vaccine in Nepal. ${ }^{10}$ As per WHO position paper 2018, in the typhoid endemic settings, typhoid vaccines should be used as one of the preventive measures to combat the
${ }^{1}$ Central Department of Biotechnology, Tribhuvan University, Kirtipur, Kathmandu, Nepal

2,3 International Vaccine Institute, Republic of Korea

Corresponding Author: Birendra Prasad Gupta, Central Department of Biotechnology, Tribhuvan University, Kirtipur, Kathmandu, Nepal, Phone: +977 9818947391, e-mail: birendraphd@gmail.com

How to cite this article: Gupta BP, Saluja T, Sahastrabuddhe S. Epidemiology of Typhoid in Nepal: Review of Literature to Identify High Burden Area for Potential Use of Typhoid Vaccine. Pediatr Inf Dis 2021;3(2):51-56.

Source of support: Nil

Conflict of interest: None

menace of the disease. ${ }^{11}$ With the availability of Gavi funding, many eligible countries are planning to include the vaccine in their routine immunization programs. Nepal being Gavi eligible country, Government may decide to implement the TCV in near future. Keeping in mind the high possibility of the same, an overview of the typhoid fever burden in Nepal was planned.

This review would describe the prevailing condition of enteric fever in Nepal as well as its diagnostic limitations, resistance patterns, and prophylaxis measures like vaccine and future directions. 


\section{Materials and Methods}

\section{Literature Search and Inclusion Criteria}

We conducted a comprehensive search of online databases, Medline, Embase, Cochrane, and WHO website to screen publications on enteric fever in Nepal till December 2018. Search terms included "enteric fever", "diagnosis", "epidemiology", and "Nepal". Using the same search terms, we also explored medexplorer, medscape, medhunt, Google scholar, and other open grey journals databases for any information related to enteric fever in Nepal. For unpublished reports or other relevant information, we also searched online disease monitoring systems the Program for Monitoring Emerging Diseases (ProMed), Global Infectious Diseases and Epidemiology Network (GIDEON) database, and official websites of the Department of Health Services (DoHS) and Ministry of Health and Population (MoH\&P), Government of Nepal (GoN). Publications included were in the English language which reported typhoid and paratyphoid as an etiology of enteric fever through the hospital, laboratory, or community-based surveillance in Nepal. We also included outbreak reports of enteric fever in Nepal (Flowchart 1).

\section{Data Abstraction and Analysis}

The relevant published data on enteric fever meeting eligibility criteria were sorted in Microsoft Excel 2007. The data included the year of publication, study period, methodology, number of cases, demographics, and other distinct and relevant findings. All data analysis and visualization for the review were performed using Microsoft Excel 2007.

\section{Results}

\section{Epidemiology of Enteric Fever in Nepal}

Nepal is a relatively small country with a population of 29 million having significant geographic, social, and religious diversity. Enteric fever is endemic all over the country and proves to be a huge burden on government and private healthcare facilities. The prevalence of typhoid fever is high throughout the country which includes mountains, Kathmandu valley (capital city of Nepal, also known as the capital of enteric disease), and southern belts (Terai) of Nepal, and most of the cases are reported from May to October. ${ }^{12}$

Flowchart 1: Literature search and screening process used to determine the eligibility of publications on typhoid in Nepal

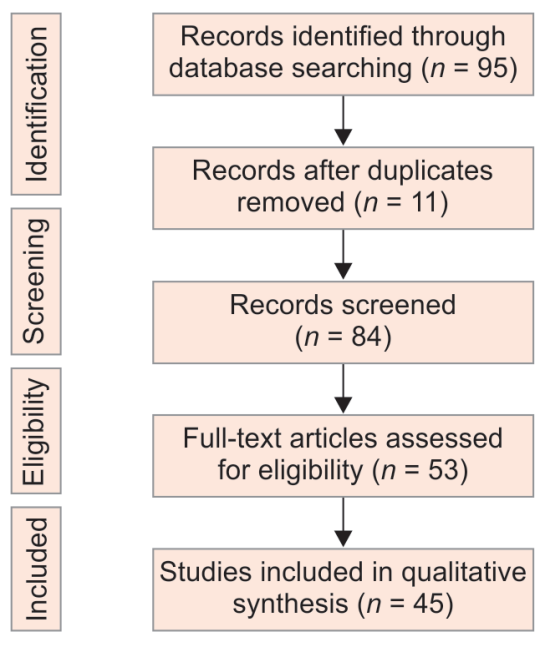

Additionally, in most healthcare facilities, it is one of the leading diagnoses for fever. World Health Organization conservatively estimates the annual prevalence of typhoid fever is $0.3 \%$ in the country. ${ }^{13}$

The first typhoid case in Nepal was reported from an adult British Nepalese soldier from Dharan in 1984 followed by an infant in $1989 .{ }^{14}$ Enteric fever episodes were reported sporadically at healthcare facilities in a densely populated area of Kathmandu valley ${ }^{15}$ which were followed by a different outbreak of S. typhi and paratyphi $A$ in the valley. ${ }^{16}$ In a decade (1993-2003), a total of 82,467 blood cultures were carried out in Kathmandu valley of which 12,252 bacteria were isolated. Out of the isolated bacterium, Salmonella was found positive in 9124 (74.5\%) blood cultures: 6,447 (70.7\%) for Salmonella enterica serotype typhi (S. typhi) and 2,677 (29.3\%) for Paratyphi A (S. paratyphi A). ${ }^{17}$ In 2004, Salmonella enterica serotype typhi was detected from 368 patients in Kathmandu ${ }^{9}$ which included 30 typhoid patients from Kathmandu Medical College and Teaching Hospital; ${ }^{18}$ at the same year, 112 cases from Dhulikhel hospital; ${ }^{19}$ while 189 cases were reported from Bir Hospital in $2006 .{ }^{20}$ Salmonella enterica serotype Paratyphi $A$ appeared as a significant source of enteric fever in Kathmandu in $2006 .{ }^{21} \mathrm{~S}$. typhi and S. paratyphi A were also isolated from gallbladders of 24 cholecystectomy patients ${ }^{22}$ and immunoreactivity was found in 13 chronic biliary carriers of S. typhi in Kathmandu. ${ }^{23} \mathrm{~A}$ fatal myocarditis complicating typhoid fever was reported in an Israeli traveler returning from Nepal. ${ }^{24}$

Typhoid disease burden is not confined to Kathmandu; many cases have been reported from outside Kathmandu valley as well. A large number of ( $n=5963)$ typhoid fever were recorded from Bharatpur during 2002 (population, 92,214), ${ }^{25} 132$ strains of $S$. enterica typhi, isolated from 2,568 blood samples from the eastern part of Nepal with one case of acute febrile encephalopathy ${ }^{26}$ and 82 cases of enteric fever in the western part of Nepal between 2000 and $2005 .^{27,28}$

The enteric fever was laboratory (serology and blood culture) confirmed in all five developmental regions. Since then, sporadic cases and/or outbreaks have continued validating the endemicity of enteric fever in the country (Fig. 1). The enteric fever-wave spread in different regions in the country and has been detected every year in one to two particular regions. The past 5 year data reveals that the number of cases of typhoid is on increase in all developing regions, except in the far western region the cases were slightly decreasing from 2013/2014 to 2014/2015 but eventually follows increasing trend after 2015/2016. The increasing rate of typhoid cases seems similar in the case of other regions (Fig. 1). A large number of cases was detected from province 5 in 2015/2016 which includes both Terai and hilly regions of Nepal (Figs 2 and 3 ).

The cases of enteric fever were reported from all geographical domains, as low as $300 \mathrm{~m}$ below the sea level of Terai regions (Morang, Sunsari, Dhanusha, Mahottari, Rautahat, Chitwan, Banke, and Kailali district), to Kathmandu valleys of upland Hill and Mountain regions which is at an altitude of 2,500 $\mathrm{m}$ above sea level in 2015/2016 (Fig. 2). From a gender perspective, men were affected more than women (Annual Report, Department of Health Service).

\section{Discussion}

Humans are the only reported host for typhoidal Salmonella, and the transmission is principally through food or water contaminated with human feces. In Nepal, habitant of 29 million people, the 


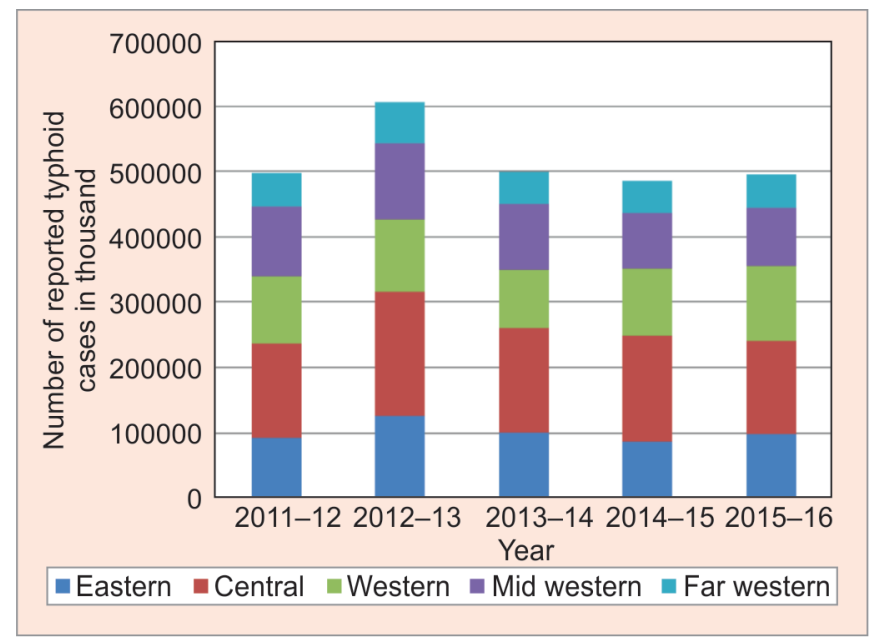

Fig. 1: Reported number of typhoid cases to the Department of Health Services by Region, 2011-2016

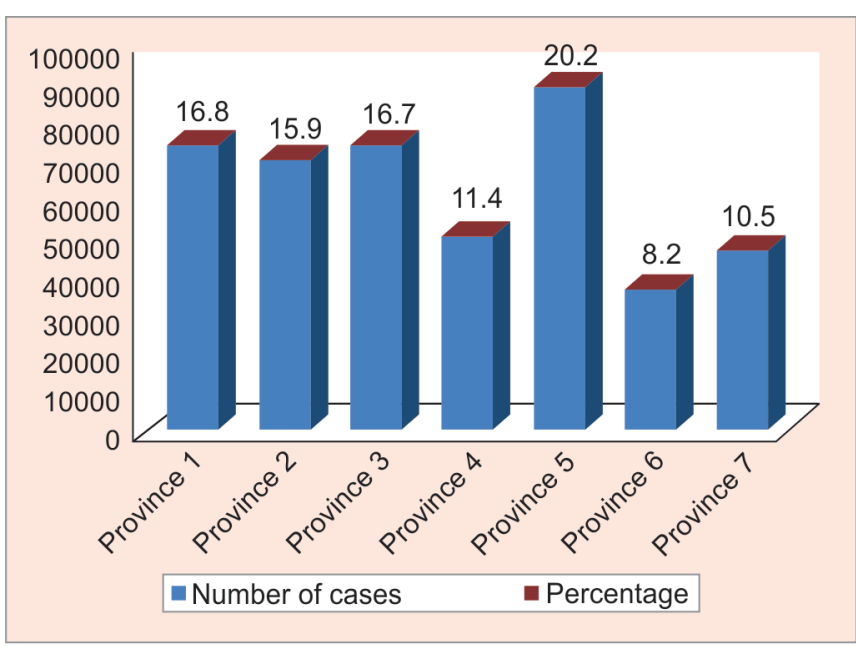

Fig. 3: Reported number of typhoid cases to the department of health services by province, 2015/2016

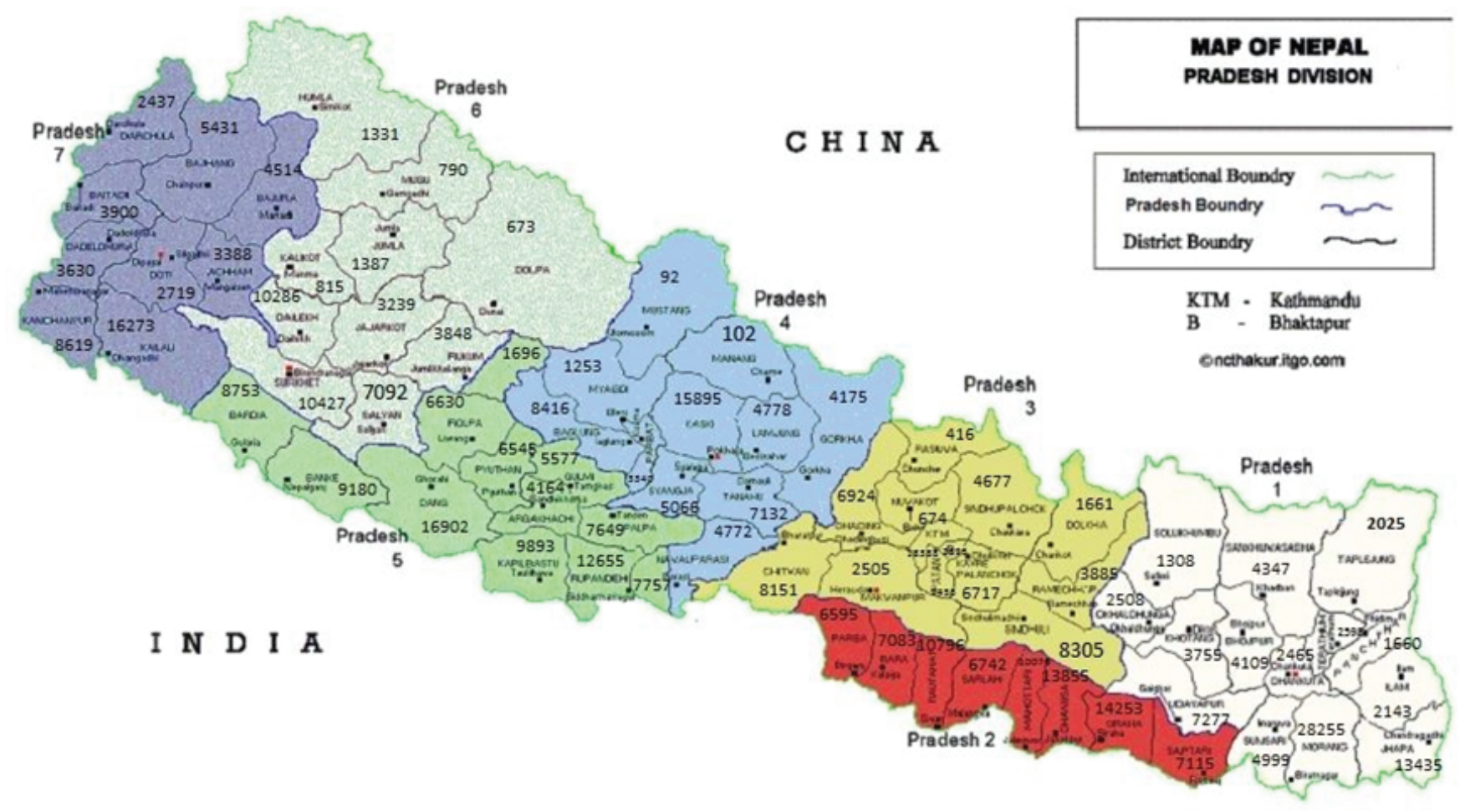

Fig. 2: Reported number of clinically diagnosed typhoid cases to the department of health services by districts, 2016 (map with typhoid case designed by authors)

majority of people (81\%) live in rural areas and only $19 \%$ in an urban area who have access to sanitary facilities, and the majority of them still rely on primitive sources for drinking water. ${ }^{29}$ Most of the water supply lines run beside drainage channels resulting in the contamination of piped drinking water supply. ${ }^{30,31}$ Several studies show that microbial counts in drinking water are above the recommended levels and about $89 \%$ of households do not even treat their drinking water. ${ }^{30}$ Due to the absence of enough waste management facilities, each day, only $31.5 \%$ of sewage from large cities can be treated while $68.5 \%$ of untreated sewage contaminates surface and groundwater. ${ }^{30}$ The factors linked to enteric fever include lower social status, overcrowding, illiterate population, living in a rented room with poor facilities, unhealthy use of latrine, and habit of not washing wash hands. In Nepal, the disease burden is comparatively high compared to developed countries, and significant social, economic, and physical costs from typhoid fever affect low-income earning households and communities throughout the country.

Isolation of the causative agent, Salmonella, from bone marrow culture is an ideal gold standard for diagnosis ${ }^{30}$ but it is 
severely limited by the availability of expertise in underdeveloped countries like Nepal. Alternatively, the widely used blood culture for pathogen isolation is also limited by the false-negative results due to its poor sensitivity of $40-60 \%$ and the time duration of diagnosis ${ }^{31-33}$ especially when the antibiotic usage is before hospital admittance, which is a common practice in Nepal. ${ }^{27}$ Although all of the above-mentioned facilities are available, the Widal test is most commonly used in the country due to limited resources for blood and bone marrow culture. ${ }^{34}$ There is a need for an increase in the diagnostic capacity for enteric fever in Nepal. ${ }^{35}$ Besides this, the accurate clinical diagnostic criteria could be a very helpful tool for the diagnosis of enteric fever when a culture facility is not available (Table 1).

The best strategies to control typhoid are based upon three interventions: vaccination, healthy living habits, water, sanitation, and hygiene (WASH), and checking of antibiotic resistance. Though vaccines for S. typhi are available for more than a hundred years both the oral live-attenuated Ty21a and the injectable Vi polysaccharide vaccine (ViPS) in use, especially in the travelers' market for many years have moderate efficacy (50-70\%), short duration of protection and poor immunogenicity among infants and young children. ${ }^{42}$ Thus, despite proven effectiveness in reducing typhoid incidence in some regions, they are not extensively used in endemic countries. However, with the use of typhoid conjugate vaccines, it induces better protection than polysaccharide vaccines and provides protective immunity in children under 2 years old, there is a strong push from the scientific world including WHO to use typhoid vaccines in endemic settings.

Conjugate S. paratyphi A vaccines are also under the process of development and phase 1 and II trial outcome has proved to be safe and immunogenic. ${ }^{43}$ The modeling data argue that conjugate vaccines are likely to provide direct and herd immunity and could be a very important tool in combating the disease burden when contemporarily adopting other interventions such as improvements

Table 1: Summary of publications reported on typhoid in Nepal

\begin{tabular}{|c|c|c|c|c|}
\hline Study period & Study design & Study area & Summary of findings & Ref. \\
\hline $\begin{array}{l}\text { January } \\
2000 \text { to } \\
\text { December } \\
2004\end{array}$ & $\begin{array}{l}\text { 2,568 patients with } \\
\text { suspected enteric } \\
\text { fever }\end{array}$ & $\begin{array}{l}\text { Eastern Nepal (B.P. } \\
\text { Koirala Institute of } \\
\text { Health Sciences) }\end{array}$ & $\begin{array}{l}132 \text { strains of S. typhi were isolated from } 2,568 \text { blood culture sam- } \\
\text { ples. Of the } 132 \text { isolates, } 35 \text { ( } 26.4 \%) \text { were MDR showing simultane- } \\
\text { ous resistance to ampicillin, chloramphenicol, and co-trimoxazole } \\
\text { which are first-line anti-typhoidal drugs }\end{array}$ & $\begin{array}{l}\text { Khanal } \\
\text { et al. }\end{array}$ \\
\hline $\begin{array}{l}\text { April and } \\
\text { October } \\
2011\end{array}$ & $\begin{array}{l}103 \text { febrile patients } \\
\text { with culture-con- } \\
\text { firmed enteric fever } \\
\text { were enrolled during } \\
\text { the study }\end{array}$ & $\begin{array}{l}\text { Kathmandu (Patan } \\
\text { Hospital) }\end{array}$ & $\begin{array}{l}48 \%(49 / 103) \text { were positive for S. typhi and } 52 \%(54 / 103) \text { were posi- } \\
\text { tive for S. paratyphi A }\end{array}$ & $\begin{array}{l}\text { Karkey } \\
\text { et al. }{ }^{16}\end{array}$ \\
\hline $\begin{array}{l}\text { April } 1992 \\
\text { to Decem- } \\
\text { ber } 2014\end{array}$ & $\begin{array}{l}224,741 \text { individual } \\
\text { patient blood sam- } \\
\text { ples }\end{array}$ & $\begin{array}{l}\text { Kathmandu (Patan } \\
\text { Hospital) }\end{array}$ & $\begin{array}{l}\text { Of } 224,741 \text {, the } 173,892(77.4 \%) \text { were culture-negative, } 10,496(4.7 \%) \\
\text { were positive for non-Salmonella bacteria, and } 20,496(9.1 \%) \text { were } \\
\text { contaminated or contained fungi }\end{array}$ & $\begin{array}{l}\text { Zellweger } \\
\text { et al. }\end{array}$ \\
\hline $\begin{array}{l}\text { January } \\
2008 \text { and } \\
\text { July } 2012\end{array}$ & $\begin{array}{l}9,901 \text { enteric fever } \\
\text { cases from the dif- } \\
\text { ferent hospital of } \\
\text { Kathmandu valley }\end{array}$ & Kathmandu & $\begin{array}{l}\text { 1,881 of these were confirmed typhoid cases from five hospitals in } \\
\text { the Kathmandu district. Approximately } 70 \% \text { of the cases involved } \\
\text { children under } 15 \text { years old. 1,281 cases were confirmed as S. para- } \\
\text { typhi }\end{array}$ & $\begin{array}{l}\text { Bajracharya } \\
\text { et al. }^{37}\end{array}$ \\
\hline $\begin{array}{l}\text { October } \\
2012 \text { and } \\
\text { October } \\
2014\end{array}$ & $\begin{array}{l}116 \text { patients with } \\
\text { bacteremic TF were } \\
\text { screened for the } \\
\text { comparative trial }\end{array}$ & Dhulikhel hospital & $\begin{array}{l}\text { Salmonella typhi accounted for } 64 / 116(55.7 \%) \text { of all isolates, while } \\
\text { Salmonella paratyphi accounted for } 52 / 116(44.3 \%) ; 42 \text { of the lat- } \\
\text { ter were identified as Salmonella paratyphi A, and } 9 \text { as Salmonella } \\
\text { paratyphi B (one isolate was only identified as Salmonella paratyphi } \\
\text { without serovar) }\end{array}$ & $\begin{array}{l}\text { Petersiel } \\
\text { et al. }\end{array}$ \\
\hline $\begin{array}{l}\text { February } \\
1987 \text { to } \\
\text { February } \\
1989\end{array}$ & $\begin{array}{l}\text { Total traveler patient } \\
\text { visits during the } \\
\text { study period were } \\
\text { approximately } 1 \\
1,000\end{array}$ & $\begin{array}{l}\text { Non-Nepalese pa- } \\
\text { tients presenting to } \\
\text { the western-staffed } \\
\text { outpatient clinic } \\
\text { (CIWEC) }\end{array}$ & $\begin{array}{l}\text { A total of } 45 \text { cases of enteric fever were diagnosed during the study. } \\
\text { Of these, } 33 \text { occurred in travelers and } 12 \text { among foreign residents }\end{array}$ & $\begin{array}{l}\text { Shlim } \\
\text { et al. }\end{array}$ \\
\hline $\begin{array}{l}\text { December } \\
2014 \text { and } \\
\text { October } \\
2015\end{array}$ & $\begin{array}{l}\text { Isolates were col- } \\
\text { lected from } 109 \\
\text { cases of bacteremia }\end{array}$ & $\begin{array}{l}\text { Kathmandu (Trib- } \\
\text { huvan University } \\
\text { Teaching Hospital) }\end{array}$ & $\begin{array}{l}23 \text { cases of bacteremia due to S. paratyphi A, and } 86 \text { cases of bacte- } \\
\text { remia due to S. typhi were identified. Among the } 23 \text { cases of bactere- } \\
\text { mia due to S. paratyphi A, } 13 \text { patients ( } 56.5 \%) \text { were male, the median } \\
\text { age was } 21 \text { years [interquartile range (IQR): } 17-23 \text { years, range: } 5-68 \\
\text { years]. Among the } 86 \text { cases of bacteremia due to S. typhi, } 51 \text { patients } \\
\text { (59.3\%) were male, the median age was } 21 \text { years (IQR: } 17-26 \text { years, } \\
\text { range: } 4-70 \text { years) }\end{array}$ & $\begin{array}{l}\text { Sherchan } \\
\text { and oth- } \\
\text { ers }^{40}\end{array}$ \\
\hline $\begin{array}{l}\text { April } 2007 \\
\text { to March } \\
2008\end{array}$ & $\begin{array}{l}9,856 \text { blood samples } \\
\text { collected for culture } \\
\text { to find out the prev- } \\
\text { alence and antibiotic } \\
\text { sensitivity pattern of } \\
\text { Salmonella typhi and } \\
\text { paratyphi isolate }\end{array}$ & $\begin{array}{l}\text { Kathmandu (Kanti } \\
\text { Children's Hospital) }\end{array}$ & $\begin{array}{l}\text { Out of total, } 235 \text { ( } 2.0 \%) \text { were positive for S. typhi and paratyphi A. } \\
\text { S. typhi was found to be most sensitive to cefotaxime }(100.0 \%) \\
\text { followed by ceftriaxone }(98.9 \%) \text {, ofloxacin }(93.5 \%) \text {, cotrimoxazole } \\
\text { ( } 93.5 \%) \text { and chloramphenicol }(93.2 \%) \text { and was least sensitive to } \\
\text { amoxyccilin ( } 66.7 \%) \text { followed by ciprofloxacin }(86.6 \%) \text {. S. paratyphi } \\
\text { also was found to be most sensitive to cefotaxime (100.0\%), followed } \\
\text { by ceftriaxone ( } 97.4 \%) \text {, cotrimoxazole }(97.1 \%) \text { and chloramphenicol } \\
\text { (92.5\%) and was least sensitive to amoxycillin }(15.0 \%) \text { followed by } \\
\text { ciprofloxacin }(51.3 \%) \text { and ofloxacin }(70.3 \%)\end{array}$ & $\begin{array}{l}\text { Prajapati } \\
\text { et al. }{ }^{41}\end{array}$ \\
\hline
\end{tabular}


in detection and timely treatment of disease, safe drinking water, improved sanitation, and general living conditions. ${ }^{44}$

\section{Conclusion}

Based on published literature, Nepal has been endemic for typhoid with outbreaks being reported episodically in Terai and hilly regions. However, our understanding of the actual disease burden is limited by an incomplete surveillance system and diagnostic capacity. Efforts are required to develop improved, proactive, laboratory-based surveillance systems that can forecast impending typhoid outbreaks in this country. This will alert the public to take action and physicians to diagnose at an early stage for effective treatment of typhoid cases in the different regions of Nepal. The implementation of systematic typhoid surveillance for reliable diagnosis is required to identify the actual disease burden and to understand the geographical disease distribution and inform the priority areas to target for typhoid prevention. Though improved water and sanitation systems are the ultimate solutions to eliminate typhoid, this requires sustained long-term investments by donors and affected countries. Currently available vaccines are effective at preventing typhoid and controlling outbreaks and should be used proactively.

\section{Acknowledgments}

The authors are thankful to the staff members of EDCD for their help during manuscript preparation.

\section{References}

1. Bhutta ZA, Gaffey MF, Crump JA, et al. Typhoid fever: way forward. Am J Trop Med Hygiene 2018;99(3_Suppl):89-96. DOI: 10.4269/ ajtmh.18-0111.

2. Stanaway JD, Reiner RC, Blacker BF, et al. The global burden of typhoid and paratyphoid fevers: a systematic analysis for the global burden of disease study 2017. Lancet Infect Dis 2019;19(4):369-381. DOI: 10.1016/ S1473-3099(18)30685-6.

3. Kim J-H, Mogasale V, Im J, et al. Updated estimates of typhoid fever burden in sub-Saharan Africa. Lancet Global Health 2017;5(10):e969. DOI: 10.1016/S2214-109X(17)30328-5.

4. Buckle GC, Walker CLF, Black RE. Typhoid fever and paratyphoid fever: systematic review to estimate global morbidity and mortality for 2010. J Global Health 2012;2(1):010401. DOI: 10.7189/jogh.01.010401.

5. Divyashree S, Nabarro L, Veeraraghavan B, et al. Enteric fever in India: current scenario and future directions. Tropl Med Internat Health 2016;21(10):1255-1262. DOI: 10.1111/tmi.12762.

6. Harris JB, Brooks WA. Typhoid and paratyphoid (enteric) fever. In: Hunter's tropical medicine and emerging infectious diseases, ed. Elsevier; 2020. pp. 608-616.

7. Abatcha MG, Effarizah ME, Rusul G. Antibiotic susceptibility and molecular characterization of Salmonella enterica serovar Paratyphi $B$ isolated from vegetables and processing environment in Malaysia. Int J Food Microbio 2019;290:180-183. DOI: 10.1016/j. ijfoodmicro.2018.09.021.

8. Crump JA. Progress in typhoid fever epidemiology. Clin Infect Dis 2019;68(Supp_1):S4-S9. DOI: 10.1093/cid/ciy846.

9. Shrestha S, Amatya R, Shrestha RK, et al. Frequency of blood culture isolates and their antibiogram in a teaching hospital. J Nepal Med Associat 2014;52(193):692-696. DOI: 10.31729/jnma.2295.

10. Theiss-Nyland K, Shakya M, Colin-Jones R, et al. Assessing the impact of a Vi-polysaccharide conjugate vaccine in preventing typhoid infections among Nepalese children: a protocol for a phase III, randomized control trial. Clin Infect Dis 2019;68(Supp_2):S67-S73. DOI: $10.1093 /$ cid/ciy1106.
11. Organization WH. Typhoid vaccines: WHO position paper, March 2018-recommendations. Vaccine 2019;37(2):214-216. DOI: 10.1016/j. vaccine.2018.04.022.

12. Britto CD, Dyson ZA, Duchene $S$, et al. Laboratory and molecular surveillance of paediatric typhoidal Salmonella in Nepal: antimicrobial resistance and implications for vaccine policy. PLoS Neglec Trop Dis 2018;12(4):e0006408. DOI: 10.1371/journal.pntd.0006408.

13. Organization $\mathbf{W H}$, Research and development to meet health needs in developing countries: strengthening global financing and coordination: report of the consultative expert working group on research and development: financing and coordination. 2012.

14. Klonin $\mathrm{H}$, Minelli $\mathrm{E}$, Adhikari N. Three unusual cases of Salmonella infection in infants. Ann Trop Paediat 1989;9(4):240-242. DOI: 10.1080/02724936.1989.11748639.

15. Karkey A, Arjyal A, Anders KL, et al. The burden and characteristics of enteric fever at a healthcare facility in a densely populated area of Kathmandu. PLoS One 2010;5(11):e13988. DOI: 10.1371/journal. pone.0013988.

16. Karkey A, Thompson CN, Thieu NTV, et al. Differential epidemiology of Salmonella Typhi and Paratyphi A in Kathmandu, Nepal: a matched case control investigation in a highly endemic enteric fever setting. PLoS Neglec Trop Dis 2013;7(8):e2391. DOI: 10.1371/journal. pntd.0002391.

17. Maskey AP, Basnyat $B$, Thwaites GE, et al. Emerging trends in enteric fever in Nepal: 9124 cases confirmed by blood culture 1993-2003. Transact Royal Soc Trop Med Hygiene 2008;102(1):91-95. DOI: 10.1016/j.trstmh.2007.10.003.

18. Mathura K, Gurubacharya D, Shrestha A, et al., Clinical profile of typhoid patients. 2003.

19. Sharma N, Koju R, Karmacharya B, et al., Typhoid fever in Dhulikhel hospital, Nepal. 2004.

20. Karmacharya B, Sharma V, Results of typhoid perforation management: our experience in Bir Hospital, Nepal. 2006.

21. Woods CW, Murdoch DR, Zimmerman MD, et al. Emergence of Salmonella enterica serotype Paratyphi A as a major cause of enteric fever in Kathmandu, Nepal. Transact Royal Soc Trop Med Hygiene 2006;100(11):1063-1067. DOI: 10.1016/j.trstmh.2005.12.011.

22. Dongol S, Thompson CN, Clare S, et al. The microbiological and clinical characteristics of invasive Salmonella in gallbladders from cholecystectomy patients in Kathmandu, Nepal. PLoS One 2012;7(10):e47342. DOI: 10.1371/journal.pone.0047342.

23. Charles RC, Sultana T, Alam MM, et al. Identification of immunogenic Salmonella enterica serotype typhi antigens expressed in chronic biliary carriers of S. Typhi in Kathmandu, Nepal. PLoS Neglec Trop Dis 2013;7(8):e2335. DOI: 10.1371/journal.pntd.0002335.

24. Palombo M, Margalit-Yehuda R, Leshem E, et al. Near-fatal myocarditis complicating typhoid fever in a traveler returning from Nepal. J Travel Med 2013;20(5):329-332. DOI: 10.1111/jtm.12048.

25. Lewis MD, Serichantalergs O, Pitarangsi $C$, et al. Typhoid fever: a massive, single-point source, multidrug-resistant outbreak in Nepal. Clin Infecti Dis 2005;40(4):554-561. DOI: 10.1086/427503.

26. Khanal B, Sharma SK, Bhattacharya SK, et al. Antimicrobial susceptibility patterns of Salmonella enterica serotype typhi in eastern Nepal. J Health, Populat Nutrit 2007;25(1):82.

27. Malla T, Malla KK, Thapalial A, et al. Enteric fever: a retrospective 6-year analysis of 82 paediatric cases in a teaching hospital. Kathmandu Univer Med J 2007;5(2):181-187.

28. Singh RR, Chaudhary S, Bhatta NK, et al. Clinical and etiological profile of acute febrile encephalopathy in eastern Nepal. Indian J Pediatr 2009;76(11):1109-1111. DOI: 10.1007/s12098-009-0233-8.

29. Group WB: World development indicators 2014: World Bank Publications; 2014.

30. Parry CM, Wijedoru L, Arjyal A, et al. The utility of diagnostic tests for enteric fever in endemic locations. Expert Rev Anti-infect Ther 2011;9(6):711-725. DOI: 10.1586/eri.11.47.

31. Farooqui B, Khurshid M, Ashfaq M, et al. Comparative yield of Salmonella typhi from blood and bone marrow cultures in patients 
with fever of unknown origin. J Clin Pathol 1991;44(3):258-259. DOI: 10.1136/jcp.44.3.258.

32. Wain J, Bay PVB, Vinh H, et al. Quantitation of bacteria in bone marrow from patients with typhoid fever: relationship between counts and clinical features. J Clin Microbiol 2001;39(4):1571-1576. DOI: 10.1128/ JCM.39.4.1571-1576.2001.

33. Ley B, Thriemer K, Ame SM, et al. Assessment and comparative analysis of a rapid diagnostic test (Tubex $(R))$ for the diagnosis of typhoid fever among hospitalized children in rural Tanzania. BMC Infect Dis 2011;11(1):147. DOI: 10.1186/1471-2334-11-147.

34. Pokhrel BM, Karmacharya R, Mishra SK, et al. Distribution of antibody titer against Salmonella enterica among healthy individuals in nepal. Ann Clin Microbiol Antimicrob 2009;8(1):1. DOI: 10.1186/1476-07118-1.

35. Neopane A, Poudel M, Pradhan B, et al., Enteric fever: diagnostic value of clinical features. 2006

36. Zellweger RM, Basnyat B, Shrestha P, et al. A 23-year retrospective investigation of Salmonella Typhi and Salmonella Paratyph isolated in a tertiary Kathmandu hospital. PLoS Neglec Tropi Dis 2017;11(11):e0006051. DOI: 10.1371/journal.pntd.0006051.

37. Bajracharya D, Khan MI, Pach IIIA, et al. 25 Years after Vi typhoid vaccine efficacy study, typhoid affects significant number of population in Nepal. PLoS One 2014;9(1):e77974. DOI: 10.1371/journal. pone.0077974.
38. Petersiel N, Shresta S, Tamrakar R, et al. The epidemiology of typhoid fever in the Dhulikhel area, Nepal: A prospective cohort study. PLoS One 2018;13(9):e0204479. DOI: 10.1371/journal.pone. 0204479.

39. Shlim DR, Schwartz E, Eaton M. Clinical importance of Salmonella paratyphi A infection to enteric fever in Nepal. J Travel Med 1995;2(3):165-168. DOI: 10.1111/j.1708-8305.1995.tb00645.x.

40. Sherchan JB, Morita M, Matono T, et al. Molecular and clinical epidemiology of Salmonella Paratyphi A isolated from patients with Bacteremia in Nepal. Am J Trop Medi Hygiene 2017;97(6):1706-1709. DOI: 10.4269/ajtmh.17-0227.

41. Prajapati B, Rai G, Rai S, et al. Prevalence of Salmonella typhi and paratyphi infection in children: a hospital based study. Nepal Med Coll J 2008;10(4):238-241.

42. Karkey A, Aryjal A, Basnyat B, et al. Kathmandu, Nepal: still an enteric fever capital of the world. J Infect Develop Count 2008;2(06): 461-465.

43. Sahastrabuddhe S, Saluja T. Overview of the typhoid conjugate vaccine pipeline: current status and future plans. Clin Infect Dis 2019;68(Supplement_1):S22-S26. DOI: 10.1093/cid/ ciy884.

44. Date KA, Bentsi-Enchill AD, Fox KK, et al. Typhoid fever surveillance and vaccine use-South-East Asia and Western Pacific regions, 2009-2013. MMWR Morbid Mortal Week Rep 2014;63(39):855. 